\title{
438 腐食表面層の力学特性評価
}

\section{Mechanical property evaluation of corroded surface layer}

\section{○正 二川 正敏（原研） 正 涌井 隆（新潟大院） 川崎 琢磨（茨城大院） 小貫薰（原研） 清水三郎（原研） 山口明久（千代田化工）}

\section{Masatoshi FUTAKAWA, Kaoru ONUKI, Sabro SHIMIZU, Japan Atomic Energy Research Institute Takashi WAKUI, Niigata University, Takuma KAWASAKI, Ibaraki University Akihisa YAMAGUTI, Chiyoda Co.}

\begin{abstract}
Micro-indentation technique was applied to evaluate the mechanical properties of corroded surface layers of Ni-alloy, $316 \mathrm{SS}$, Ti and $\mathrm{Ta}$, which were immerged into the corrosive gas environment consisting of $\mathrm{HI}+\mathrm{I}_{2}+\mathrm{H}_{2} \mathrm{O}+\mathrm{H}_{2}$. It was simulated one of environments in the thermochemical hydrogen production, IS process, developed by JAERI. In particular, the degradation due to the corrosion attack by HI and the hydrogen embrittlement is a key issue from the viewpoint of material integrity in it. The micro-indentation tests using a spherical indenter and the inverse analyses with Kalman filter were performed to quantitatively estimate material constants of corroded surface layer. Ni-alloy exhibits good corrosion resistance and Ta is remarkably influenced by the hydrogen embrittlement.
\end{abstract}

key words : Corrosion, Embrittlement, Micro-Indentation, Finite Element Method, Inverse Analysis

\section{1. 緒言}

核熱利用の一環として日本原子力研究所で開発が進めら れている熱化学水素製造法 IS プロセス ${ }^{(1)}$ は、ヨウ素(I)と硫 酸 $(\mathrm{S})$ を循環物質として用いることから、腐食性の強い工程 で構成される。したがって、腐食環境に耐えうる構造機器 及び材料の開発が本プロセスの実用化には不可欠である。 今回は水素発生工程であるヨウ化水素分解環境中における 腐食試験を実施し、ヨウ素による腐食と水素脆化挙動につ いて微小押込み試験により定量的に評価した。すなわち、 計測された押込み荷重一深さ曲線に対して、逆解析を行うこ とで、材料表面層あるいは耐食被覆層の腐食劣化特性を評 価する。

\section{2. 実験方法}

\section{1 供試材}

供試材は、316SS、Ni 基耐食合金 Ni-Alloy（19Cr-19Mo$1.8 \mathrm{Ta}) 、 \mathrm{Ti}$ 及び Ta の 4 種類である。試験片形状は $15 \times 25$ $\times 1 \sim 3 \mathrm{~mm}^{3}$ の短冊形であり、試験片表面の最終研磨は 600 番 エメリー紙である。

\section{2 腐食試験}

腐食環境はポリヨウ化水素酸溶液（ $\mathrm{HI}: \mathrm{I}_{2}: \mathrm{H}_{2} \mathrm{O}=1: 1: 6 ; \mathrm{mol}$ 比）を蒝発させたガスに水素ガスを $20 \%$ の割合で混合した ガスである。試験時間は 100 時間とした。腐食試験後、寸 法・重量測定及び試料表面・断面の顕微鏡観察を行った。

\section{3 微小押込み試験}

試料表面及び断面に対して、ベルコビッチ圧子及び球圧 子を用いた微小押込み試験を行った。球状圧子は頂角 $60^{\circ}$ の円錐圧子の先端を球状に加工したもので、曲率半径 $r$ は $5.5 \mu \mathrm{m}$ である。最大押込み荷重はいずれの測定面に対して も $98 \mathrm{mN}$ とした。

\section{4 材料定数の同定}

球状圧子により計測された押込夕荷重-深さ曲線（P-h曲 線）に対して、次に示すようにカルマン・フィルタを用い た逆解析を行い腐食表層部の材料常数の同定を行った。ま ず、材料構成式を式(1),(2)に示す指数関数型と仮定すれば、 同定すべき式中の各材料定数は $E$ ：弾性係数、 $\sigma_{\mathrm{y}}$ : 降伏応

力、 $A$ : 加工硬化係数、及び $n:$ 加工硬化指数となる。

$$
\begin{array}{ll}
\sigma=E \varepsilon & \sigma \leq \sigma_{y} \\
\sigma=A\left(\varepsilon_{0}+\varepsilon\right)^{n}, \varepsilon_{0}=\left(\sigma_{y} / A\right)^{1 / n}-\left(\sigma_{y} / E\right) & \sigma \geq \sigma_{y}
\end{array}
$$

以下、同定手順を図 1 に示す流れ図に従って概説する。 1. $\mathbf{C}_{0}, \mathbf{R}, \mathbf{E}_{0}$ 及び $I_{\max }$ を入力する。ここで、 $\mathbf{C}_{0}$ は推定する 定数の初期值、 $\mathbf{R}$ 及び $\mathbf{E}_{0}$ は測定値及び推定値の誤差、 $I_{\text {max }}$ は解析の負荷過程における $P$ - $h$ 曲線の分割数（総ステップ 数)である。

2. ステップI $\left(I=1,2, \cdots, I_{\max }\right)$ における測定値 $\mathbf{Z}_{\mathrm{I}}$ を入力する。 3. FEM 解析により、ステップ $I$ における解析值 $\mathrm{Y}_{\mathrm{I}}$ 及び変 化率 $\mathbf{H}_{\mathrm{I}}$ を算出する。

4. 各値 $\left(\mathrm{C}_{\mathrm{I}-1}, \mathbf{R}, \mathbf{E}_{\mathrm{I}-1}\right.$ 及び $\left.\mathrm{Z}_{\mathrm{I}}\right)$ と解析值 $\left(\mathrm{Y}_{\mathrm{I}}\right.$ 及び $\left.\mathrm{H}_{\mathrm{I}}\right)$ に 対して、式(3)、(4)に示すカルマン・フィルタにより推定值 $\mathrm{C}_{\mathrm{I}}$ を算出する。

$$
\begin{aligned}
& \mathrm{C}_{\mathrm{I}}=\mathrm{C}_{\mathrm{I}-1}+\mathbf{E}_{\mathrm{I}} \mathbf{H}_{\mathrm{I}} \mathbf{R}^{-1}\left(\mathbf{Z}_{\mathrm{I}}-\mathbf{Y}_{\mathrm{I}}\right) \\
& \mathbf{E}_{\mathrm{I}}=\left(\mathbf{E}_{\mathrm{I}-1}+\mathbf{H}_{\mathrm{I}}^{\mathrm{T}} \mathbf{R}^{-1} \mathbf{H}_{\mathrm{I}}\right)^{-1}
\end{aligned}
$$

再び 3 に戻り、推定された定数 $C_{1}$ を用いてステップ $I+1$ の 解析を行う。この手順を $I_{\max }$ まで繰り返し行い、最終的に $C_{\text {fin }}$ を算出する。

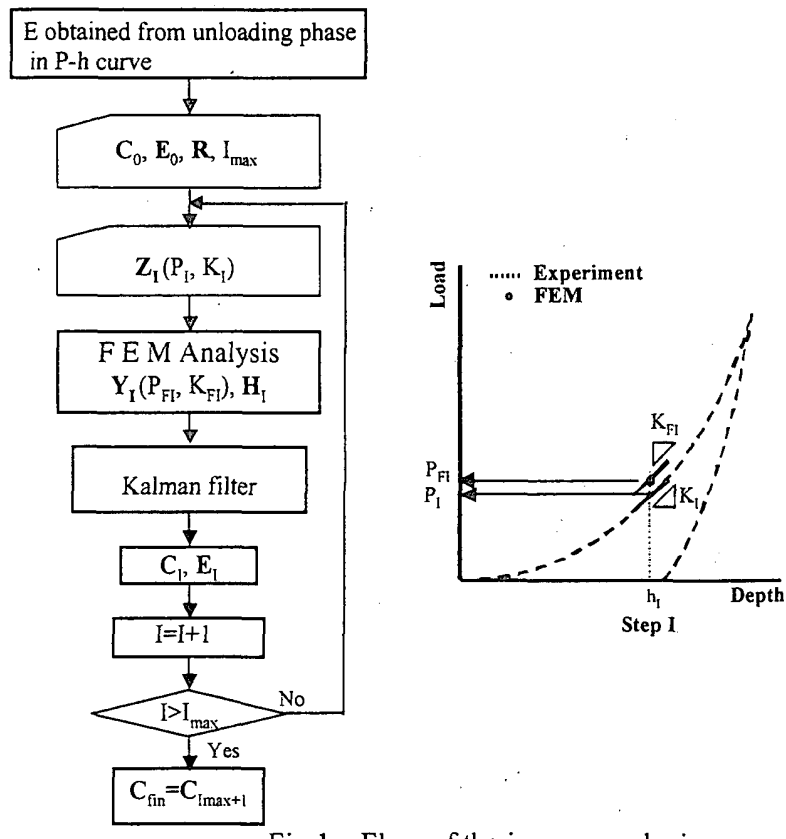

Fig.1 Flow of the inverse analysis 


\section{1 腐食速度及び腐食形態}

\section{3. 実験結果及び考察}

腐食減量から算出した腐食速度は、316SS では $0.619 \mathrm{~g} / \mathrm{mm}^{2} \mathrm{~h}$ であったが、その他の試料では非常に小さい値 を示した。また、試料断面の観察により 316SS の試料表面 には平均 $1.7( \pm 0.5) \mu \mathrm{m}$ の腐食層があり、 $\mathrm{Ti}$ では粒内に水 素化合物が生じていることが分かった。一方、Ni-Alloy 及 び Ta は、腐食による重量測定及び断面観察ではほとんど変 化は認められなかった。

3.2 力学特性

図 2 にペルコビッチ圧子により計測された各試料の代表 的な腐食前・後の $P / h-h$ 曲線を示す。なお、 $P / h-h$ 曲線の負 荷過程の傾きは硬度に比例する。また、腐食前の全試料に おいて $P / h-h$ 曲線の負荷過程で約 $0.3 \sim 0.5 \mu \mathrm{m}$ 以下の押込み 深さの領域で内部に比べて硬化する傾向が認められる。こ れは、試験片加工時に加工硬化層が表層に形成したためと 考えられる。

腐食による $P / h-h$ 曲線の変化は、3つ Type に分類できる。 すなわち、Type 1 は Ti や Ni-Alloy のように腐食前後で曲線 に変化が認められない場合、Type2 は 316SS のように負荷 初期に腐食による硬度 (傾き) の低下を示す場合、一方 Type3 は Ta のように硬度が増加する場合である。Type1 は腐食に 伴う材料表層部の力学特性がほとんど変化しなかったこと を示す。Type 2 は表層に母材より硬度の低い腐食層あるい はスケールが存在すると考えられる。そこで、傾きが変化 する押込み深さを $d$ と定義し,$d$ と変化層厚さ $T$ の関係 $\left(d / T=0.1 \sim 0.3^{(2)}\right)$ より変化層厚さを推定した。316SS の $d$ の 平均値は約 $0.3 \mu \mathrm{m}$ であるから、厚さ $T$ は約 $1 \sim 3 \mu \mathrm{m}$ となる。 この値は試料断面の写真から測定された腐食層厚さとほぼ 一致した。Type 3 は、腐食環境中に合まれる水素による脆 化が顥著となった例と考えられる。そこで、Ta 試料断面に おける見かけの硬度の変化を測定した。図 3 の見かけの硬 度 $H$ は腐食試験前の $H_{0}(=1.12 \mathrm{GPa})$ で無次元化した。試料 表面から $0.2 \mathrm{~mm}$ 以内では試料表面に近づくに従って、硬度 は増加した。さららに、試料断面に対して球状圧子を用いた 微小押込み試験を行い、2.4 節で示した同定手順に従って材 料定数を求めた。図 4 に試料表面からの距離に対する各材 料定数の变化を示す。なお、腐食前の各材料定数 $(E=192 \mathrm{GPa}$, $\left.\sigma_{\mathrm{y}}=195 \mathrm{MPa}, A=827 \mathrm{MPa}, n=0.486\right)$ で無次元化した。E 及び A は剆定位置によらずほぼ一定であるが、 $\sigma_{\mathrm{y}}$ は表面に近い ほど増加し、nは逆に減少する傾向がある。また、 $\mathrm{Ta}$ の水 素脆化の影響を受けた表層部の材料構成式を用いて、FEM による単軸引張の仮想実験を行った結果を図 5 に示す。腐 食前に比べて腐食後は最大引張強度が増加するが、均一伸 びは減少し、その傾向は試料表面に近づくほど顕著である。 水素濃度との相関など詳細は会場にて報告する。

\section{4. 結言}

4 種類の金属材料（316SS, Ni-Alloy, Ti 及び Ta）に対し て、IS プロセスのヨウ化水素分解環境を想定した条件下で 腐食試験を行った結果、316SS は腐食層を形成し、Ti は粒 内に水素化合物を生成した。Ni-Alloy は腐食層及び水素脆 化は確認されず、良好な耐食性を示すことを確認した。さ らに、微小押し込み試験と逆解析による力学特性評価から、 Ta はその表層において水素脆化を示し、最大引張強度の増 加及び均一伸びの著しい減少を示すことが分かった。

\section{参考文献}

(1) K.Onuki, H.Nakajima, I. Ioka, M.Futakawa and S.Shimizu, JAERI-Review, 94-006(1994)

(2) M. Futakawa, T. Wakui, I. Ioka and M. Eto, Jour. the Euro. Ceram. Soc. 20(2000) 1135-1143.
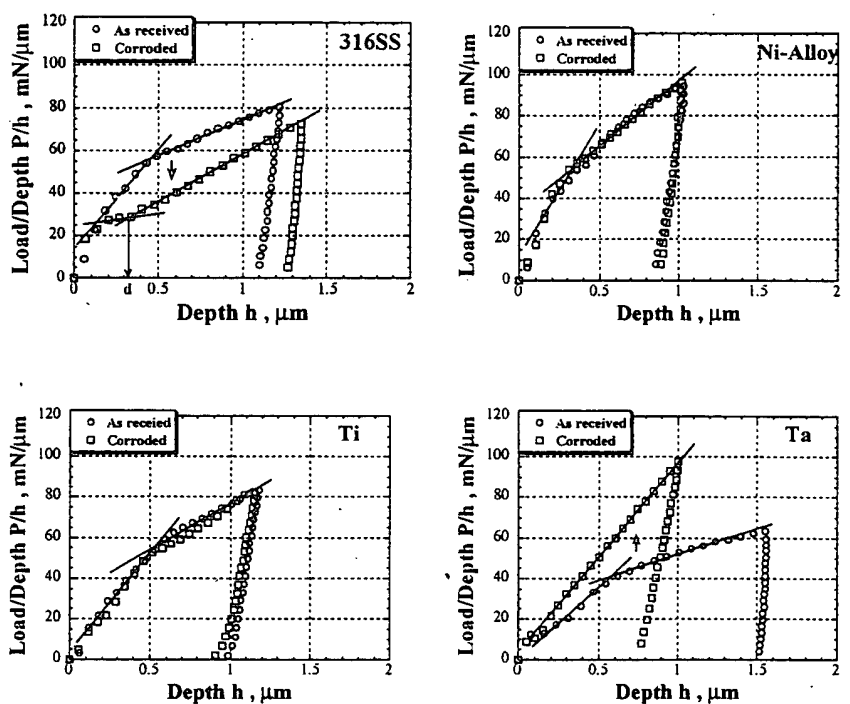

Fig. 2 Typical load-depth curves

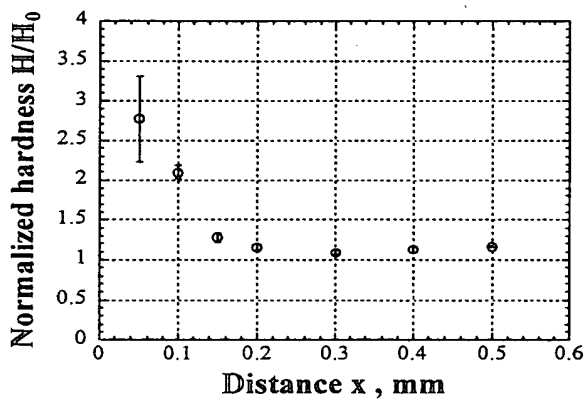

Fig. 3 Hardness distribution in cross-section of Ta

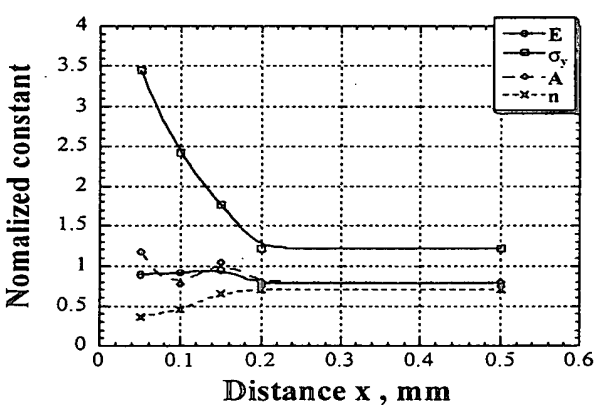

Fig.4 Evaluated material constants of embrittled Ta

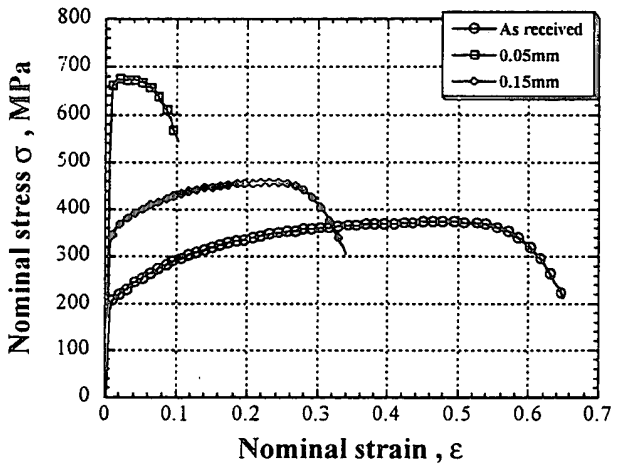

Fig. 5 Nominal stress-strain curves of embrittled Ta 